\title{
Increasing The Appreciation of Fine Art Through Participatory Murals at Perum Arjamukti Singaparna, Tasikmalaya Regency
}

\author{
Wan Ridwan Husen*, Asep Wasta, Denden Setiaji, Arni Apriani, Agi Fajri Nur, Helda Safaat, \\ Mega Utami, Widya Imardhea, Alfi Munajab
}

\begin{abstract}
Sendratasik Education Study Program, Faculty of Teacher Training and Education Muhammadiyah University of Tasikmalaya, Jl. Taman Sari Km 2.5 Tasikmalaya City *Corresponding Author: wanridwanhusen@gmail.com
\end{abstract}

\begin{abstract}
A b s t r a k
This paper aims to provide an overview of activities that seek to bring the process of art education directly to the public Community service that started from a discussion between lecturers and youth youth organizations at Perum Arjamukti Kencana in building a tourist village area around Singaparna, Tasikmalaya Regency, from this discussion arose a desire to create activities that involve residents and youth youth groups in arts-related activities. A participatory mural is a mural activity that involves the participation of citizens in its implementation, both before implementation, in its manufacture and after its creation. The method used in this research is descriptive method. The descriptive method used to increase the appreciation of fine arts through participatory murals at Perum Arjamukti Singaparna, Tasikmalaya Regency. The results obtained from research that have been carried out by residents' wishes in the mural participation process are varied, the forms of citizen participation are not only in the form of trying to scratch koas on walls to produce mural images, there are also those who participate in providing consumption, raw materials, documenting works through social media or simply just talking and taking selfies on existing murals.
\end{abstract}

\begin{tabular}{l}
\hline \multicolumn{1}{c}{ A r t i c l e I n f o } \\
\hline Article History: \\
Received 1 November 2021 \\
Revised 10 November 2021 \\
Accepted 20 November 2021 \\
Available online 15 January 2022 \\
Keywords: \\
Appreciation Of Arts, \\
Increasing Appreciation, \\
Mural Participatory \\
\end{tabular}

\section{INTRODUCTION}

Community empowerment by using an art approach. So far, not many universities, especially in the field of art, have done community service in the field of art education, especially fine arts, the area in question is especially for the people in the Tasikmalaya district. If you look at the potential they have in terms of tourism, the Singaporean community has an attractive selling point to develop apart from supporting partnership networks, this is useful for developing the creative potential of the local area. Efforts that support the achievement of village development with tourism potential that is owned to become a tourism village.

Appreciation is a process to fully understand and realize the intricacies of the work of art and to be sensitive to the aspects in it, so as to be able to enjoy and evaluate the work properly. In this case the ability to observe and respond to works of art or visual or textual forms that exist in works of art, there is not only the ability to record the characteristics (or data) that exist in 
objects, but also an attempt to find the content of the object into something meaningful. Some things that are important in observing / appreciating works of art are often observing, background information on psychological conditions when observing works.

Driven by a thought on the development of community creativity, through artistic activities that place more emphasis on economic development and regional identity, which looks at the potential of the village area itself. Given that the arts area provides an environment and practice for learners (society) to be actively involved in experiences, processes, and creative development

According to Endriawan, "Mural is drawing or painting on a relatively wide wall of media. The purpose of the mural, of course, depends on the people or interested parties. In this discussion, the author takes several mural activities that have been carried out in educational institutions and military institutions to become study materials." in line with other opinions regarding this mural is from the point of viewlrwandi, "The mural art is an artistic activity that involves community participation and has a long-term social impact. Mural art can empower viewers to imagine an idea. Not only mural works can empower, even the mural creation process can empower people to create and express themselves. Mural art can help identify the physical space of the building and also serves to describe the identity of the surrounding community with a distinctive local image. Mural art is a democratic public art form because it is based on collective aspirations and involves the active participation of the community."

\section{PARTNER PROBLEMS}

Located in a mountainous area, precisely under the foot of Mount Galunggung, Arjamukti is a comfortable area to live in, apart from the many tourist businesses. So in general, the problems faced by Nataningratan village are as follows.

1. There is a need for a citizen empowerment program that focuses on the potential of residents and the environment. But also the activity of creating a distinctive regional identity marker.

2. It is necessary to have a village empowerment program that is able to significantly boost the economic level of the villagers by looking at the potential of MSMEs, the potential of youth.

3. It is necessary to have creative products for residents so that they can become a marker of village identity, as well as initiation and encourage elements towards tourist villages.

According to Thamrin, "One of the efforts that can be done to improve the visual quality of an area is by using mural art. Besides being considered to beautify the appearance of the area, the presence of these images and colors can also strengthen the character of an area. Mural is one of the art works of space elements which is manifested in the form of large-sized paintings filling walls, ceilings and other flat surfaces. Mural also means that a painting that is made directly or indirectly has similarities to a painting. The difference lies in the special requirements that must be met by wall painting, namely the relationship with architecture/building, both from the art of design (which fulfills the aesthetic element) as well as age and maintenance as well as from the perspective of observation. (Susanto \& Mikke, 2002).

Based on this definition, it can be interpreted that the mural cannot be separated from the building, in this case the wall. The wall not only functions as a room divider but can also be used as a medium to beautify the room. Murals can also be used as a sign or marker of the identity of a place. (Ramadani \& Sabiruddin, 2018)" 
Participatory art will be important for researchers in finding alternatives to the concept of art education, considering that several research studies have focused on pedagogic art criticism, in addition to being an alternative to art teaching methods becauseparticipatory art practice which ideally upholds equality, the activities carried out by participatory art are collaborative, participatory, have become part of the creative process of creating art, this kind of creation activity is a practice of contemporary art. Participatory art is an art form or process created through the participation of people (audiences, art laypeople, community groups, the public) with artists/professional groups of artists. Participatory art can be in the form of works of art (objects) that are created as a result of collaboration between artists and participants, or can refer to participatory actions (processes) as art itself. Participatory art practice can be done with various methods and manifestations. Participatory is an absorption word from English, namely participatory. Participatory art is related to the relationship of individuals as social beings and the quality of collaboration between artists and the public. Therefore, this research is based on theories related to the social function of art, Research on participatory art has been discussed byVina Puspita, in 2017 with the title of her thesis "Practice of Participatory Fine Arts in Yogyakarta (Case Study of Ketjil moving in the Project Connect Taste". This research uses a qualitativedescriptive approach with a case study method, focusing on the process of involving residents, creating murals, until the community initiatives emerged after the Connect Rasa mural project was over.

Participatory art is not only an appreciator activity in viewing the work from a certain distance, but there is a process of interaction there, being involved in making it or interacting with the work by touching it, kissing it, writing on it, dancing with it, playing with it, even learning. of the activity. Buschmeier stated,

because of the participant's existential importance for the artwork, it affects also the understanding of the category of the artwork itself. Therefore / refer to this art practice as "participatory art".

The discussion above states that participatory art is art in which the art public becomes an active participant in the work of art. The public becomes the medium of the work of art, and becomes part of the work of art itself. In other words, without participants there is no work of art. The activities of the audience, which were previously limited to observing the practice of contemporary art, especially participatory art, underwent a radical change.

Overall, community participation in the process of making the Joint mural went well, although many residents just passed by and did not dare to join and participate in drawing this mural, while the students tried to learn while working on murals in some areas that were still empty. Because basically, murals are not only the final goal of a project, but murals are a continuous process and can be continued by anyone. This mural activity is not only one-way but can be a knowledge transfer activity, as well as adding to the relationship and family atmosphere.

\section{Mural Design}

\section{RESULTS AND DISCUSSION}

The design process in the work, is something that must be done with the aim of the design later being able to be discussed with residents, either in the form of getting input, feedback or alternative suggestions from the mural designs that have been offered. For this process, residents are directly involved to be able to contribute to the ideas and themes that will be raised, of course 
the icons or image objects displayed must be child-friendly and residents of the settlements around the foot of Mount Galunggung. Where in this case it is emphasized to be a characterizer of the area with the concept of a tourist area.

\section{Mural Making Process}

In the process of making this participatory mural of Arjamukti, residents have been directly involved, indeed not all residents are directly involved, but efforts to seek attention in increasing appreciation for fine arts have felt a response, apart from mothers and youth groups who have provided support in the form of consumption for activities together, residents who were not involved in painting the walls helped clean up the area where the mural was made, which also contributed to a number of shortcomings in terms of tools and materials. This shows that the level of citizen participation is quite good in addition to their busyness in their work activities.

\section{Murals}

In the process of making participatory murals, many community activities that support the acceleration and attractiveness of making murals in Arjamukti can be completed within the specified time. As a result, there are 12 areas of the wall that have been successfully made murals on the cooperation of the campus and residents, especially the local youth. despite all the limitations this activity was carried out well and received a pretty good appreciation from the residents of Arjamukti

\section{CONCLUSION}

This participatory mural activity is a medium for residents to decorate their village. Making part of the walls in the Arajamukti housing complex has its own characteristics, in making murals that were initiated by residents, as well as done by the residents themselves. So in general, the benefits of this program for the village include the following;

1. This village community empowerment program has succeeded in raising the potential of residents and the environment, not only with a tourism awareness campaign program. This mural program will be initiated by residents on an ongoing basis as a marker of the unique identity of the village.

2. Become a village empowerment program that is able to encourage the potential of youth and residents.

3. It is hoped that other creative products will be born, so that they can become a marker of village identity, as well as initiation and encourage the level of creativity of the residents.

\section{REFERENCES}

Buschmeier, Alice, (2013) Objection To Objects In Participatory Art , Arts With(Out) Borders Rethinking Methodologies Of Art And Culture In The Global Context 6-8 June 2013 University of Bern

Bell, Stephen, Charles, Davenport. (1991), PARTICIPATORY ART AND COMPUTERS, Identifying, analyzing and composing the characteristics of works of participatory art that use computer technology. A Doctoral Thesis of the Loughborough University

Bishop, Claire. (2012), Artificial Hells: Participatory Art and the Politics of Spectatorship, Verso Books, London.

Susanto, Mike. (2003) Fine diction: a collection of terms \& art movements, Dictiartlab \& universe arthouse, Yogyakarta. 
Susanto, Mike.(2003) Unpacking Fine Arts, Good Book Publisher and Window Publisher, Yogyakarta.

Yeni R., *) Ida Safrina Arifiani F., and Diyan Fatimatuz Zahra Mural Art as Educational Media to Prevent Vandalism in Sma Negeri 5 Yogyakarta, PELITA, Volume IV, Number 1, April 2009

Endriawan, Didit, et al. Mural as Educational Media and Community Service NATIONAL SEMINAR OF ART AND DESIGN: "BUILDING A TRADITION OF INNOVATION THROUGH RESEARCH BASED ON ART AND DESIGN PRACTICE" FBS Unesa, 28 October 2017

Suherman, Sunarto, Anggraeni Sri Prastiti Kusuma, MURAL IN THE SCHOOL ENVIRONMENT IN THE CONTEXT OF EDUCATIONAL CONSERVATION REFLECTION: Journal of Educational Science Volume 9 Number 2 June 2019 ISSN: 2087-9385 (print) and 2528-696X (online)

Himawan, MH THE WAYANG BEBER MURAL PROJECT OF NATANINGRATAN KAMPUNG AS A STRENGTHENING OF TOURISM VILLAGE IDENTITY IN TIMURAN KELURAHAN SURAKARTA Department of Fine Arts Faculty of Fine Arts and Design, ISI Surakarta Email: hendra.himawan@isi-ska.ac.id Abdi Seni Journal of Community Service, Volume 11 No. December 2, 2020

Irwandi, Ernest., Sabana, Setiawan, The Process of Embodiment of Place Identity Through Mural Art, PROCEDURE OF THE NATIONAL SEMINAR OF DESIGN AND ARCHITECTURE (SENADA) Vol.2, February 2019

Laksana DAW and Adiwibawa BAP MURAL IN MEDIA EXPOSURE AND SOCIAL LEARNING FOR THE COMMUNITY OF KAMPUNG KOTA 2, Demandia, Vol. 3 No. 1 (March 2018): 46 - 56

Martahayu, Vika, Irfansyah, Anharudin, RA. Journal of Berkejuan Community Service 224 USE OF MURAL ART IN WEST WATER BATHING RANGGUNG VILLAGE AS A SUPPORTING MEDIA BASED ON COMMUNITY SOCIAL EDUCATION 1) Elementary School Teacher Education Study Program, STKIP Muhammadiyah Bangka Belitung, Pangkal Pinang, Indonesia Volume 3, Number 2, May 2020. p -ISSN : 2614-5251 e-ISSN : 2614-526X SELAPARANG.

Thamrin, Nur Husniah., Mafazah Noviana, Assistance in Making Murals as an Effort for Visual Improvement of the Loa Buah Area, Samarinda, AKSIOLOGY: JOURNAL OF SERVICE TO THE COMMUNITY Vol.4, No.1, February 2020 Page 91 - 99 ISSN 2528-4967 (print) and ISSN 2548-219X (online)

Tri Wahyudi, Anang et al, Study of Community Participation in Mural Activities (Case Study: Wall Mural of YBPK Sekar Indah Kindergarten School Malang), JOURNAL OF VISUAL COMMUNICATION DESIGN NIRMANA, Vol. 17, No. 2, July 2017: 87-95 


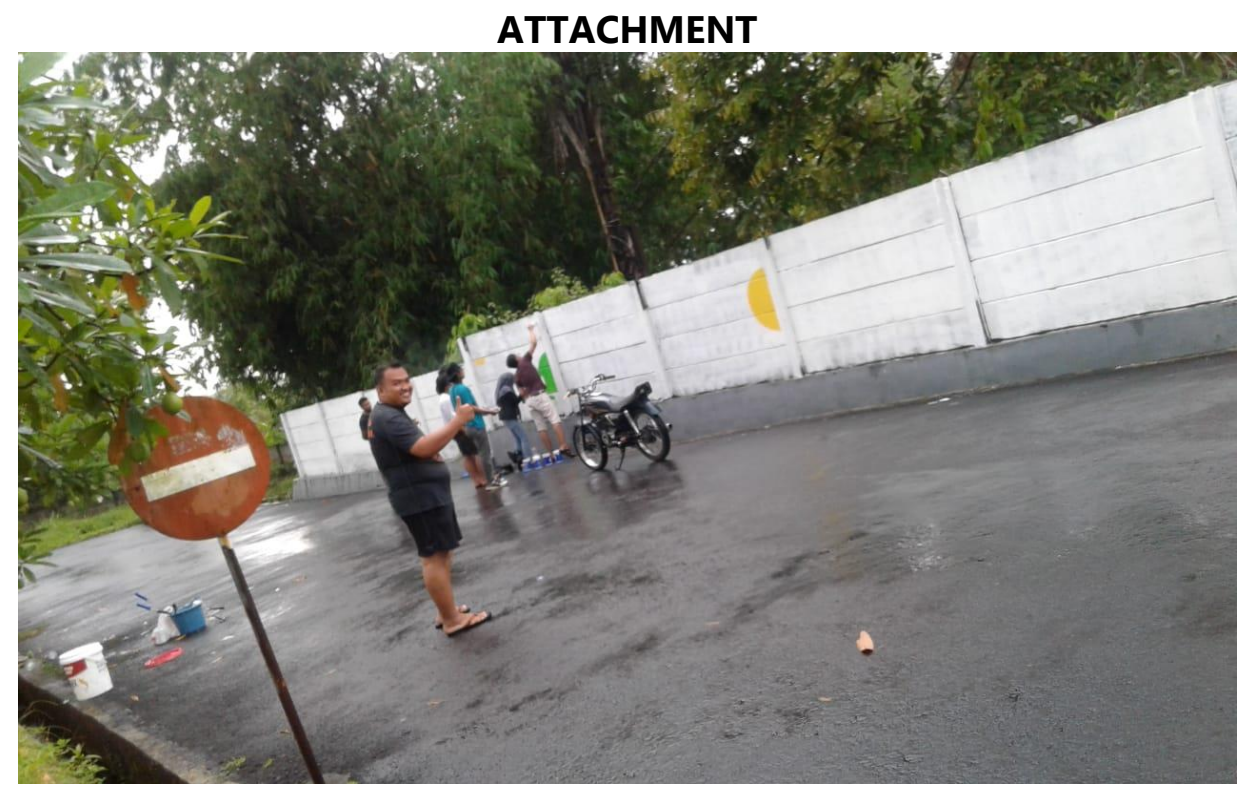

Figure 1. The process of surveying the location of the mural and the availability of materials (Author Documentation, 2020)

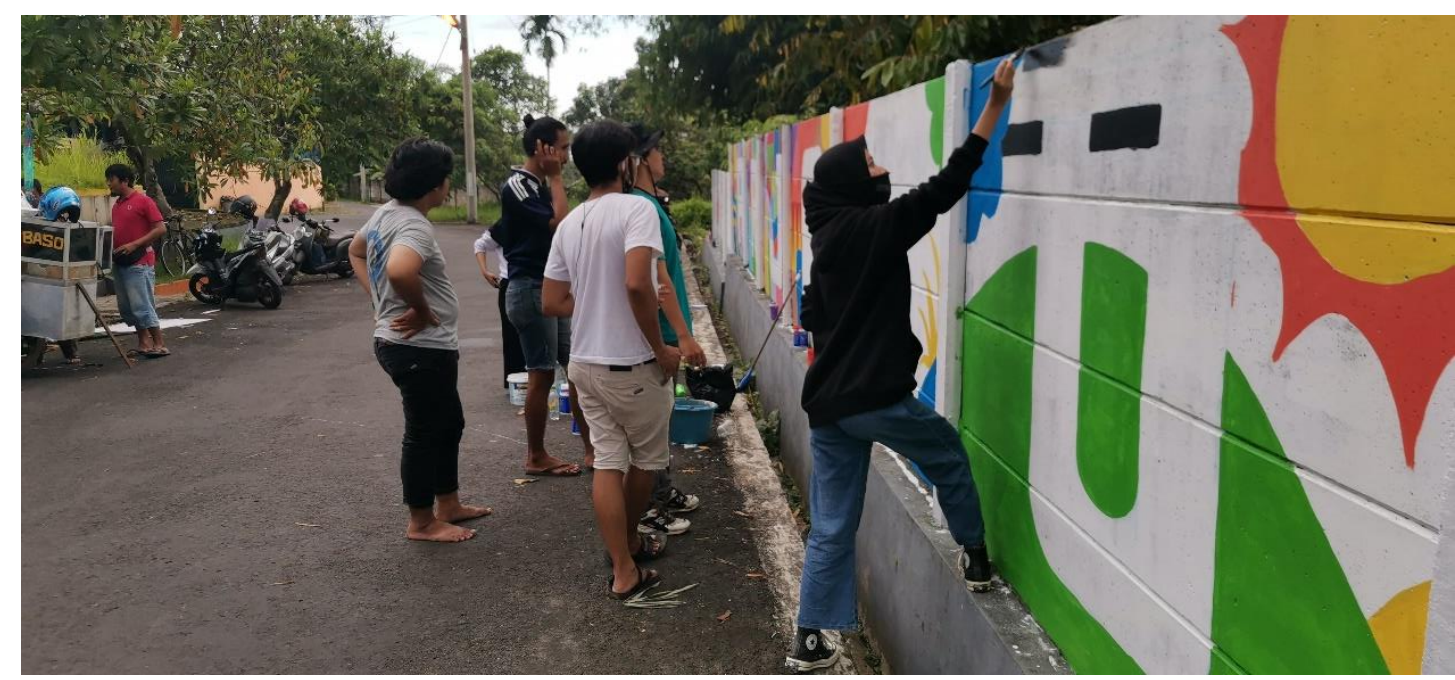

Figure 2. The process of making the mural together with the residents (Author Documentation, 2020) 


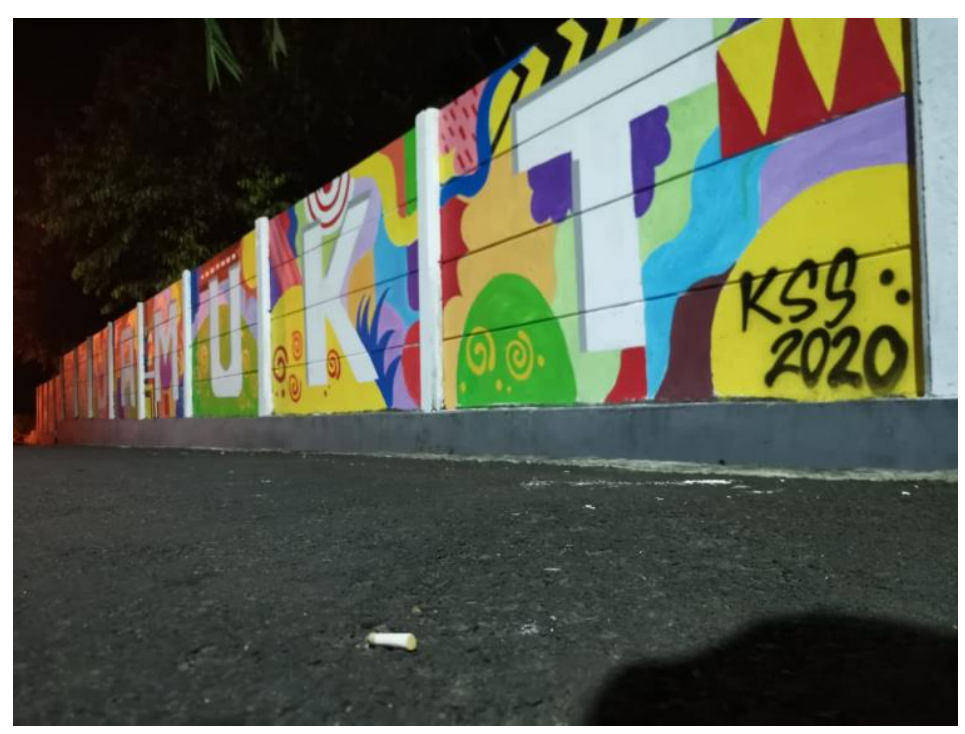

Figure 3. The result of the participatory mural of Arjamukti residents (Author Documentation, 2020) 